\title{
Positive Narratives: The Stories Young People with Social, Emotional and Behavioural Difficulties (SEBD) Tell About Their Futures
}

\author{
Dr Charlie Tellis-James and Dr Mark Fox
}

\section{Dr Charlie Tellis-James}

\section{Brief Biography}

Dr Charlie Tellis-James is an Educational Psychologist working for Achieving for Children in the London Borough of Richmond Upon Thames. After studying Psychology at Sheffield Hallam University she worked with vulnerable young people across the education, health and voluntary sectors. Charlie undertook her doctoral training at the University of East London (UEL) and is pursuing her professional interest is working with vulnerable pupils in primary and secondary schools across Richmond.

\section{Dr Mark Fox}

m.d.fox@uel.ac.uk

Programme Director - Professional Doctorate in Educational and Child Psychology

School of Psychology, University of East London, Stratford Campus, Water Lane, Stratford, London E15 4LZ

\section{Brief Biography}

Dr Mark Fox is Programme Director for the Professional Doctorate in Educational and Child Psychology at the University of East London. He has worked as an Educational Psychologist for over 30 years both for Local Authorities and the Voluntary Sector where he was head of the Advisory and Assessment Services at SCOPE. He has written extensively on the training and evidence base for educational psychology. His professional interest is in children with severe and multiple disabilities and developing their Quality of Life. 


\section{Abstract}

This research drew on positive psychology in order to offer an optimistic way of conceptualising the lives of young people who are often described as having 'SEBD' (Social, emotional, behaviour difficulties), now SEMH (Social, emotional, mental health) in the new SEND Code of Practice (2014). Positive psychology places emphasis on: the future, strengths, resources and potential, and suggests that negative experiences can build positive qualities. A life path tool was used in order to hear the stories that eight young people tell about themselves in the future. Narrative Oriented Inquiry (NOI) was used to analyse the themes of potential and growth in their stories. The young people in this research identified a range of strengths and resources in their lives that they had built as a result of earlier negative experiences. Their stories reveal their hopes and aspirations for the future. By giving these young people the opportunity to tell their stories this research permitted them to focus on where they were going, rather than where they had been.

\section{Key Words: Narratives, Positive Psychology, Social, Emotional and Behavioural Difficulties}




\section{Narrative psychology}

Narrative pervades our everyday life. We are born into a narrative world, live our lives through narrative and afterwards are described in terms of narrative (Murray, 2008, p. 111).

Narrative psychology is based on the premise that people tell stories about their lives, real or imaginary, exceptional or ordinary (Bruner, 1986). Narrative psychology is concerned with self and identity, and proposes that we live through the stories that we, and others, tell about us (Murray, 2008). This ability to think narratively and to shape and be shaped through stories is the way in which we make sense of our reality (Hiles \& Cermak, 2008). The term 'storied self' is used to refer to the way in which we create 'self' using narratives to explain what has happened or is happening to us. There has been a recent narrative turn in psychology, but interest in 'stories' has a relatively long history in the field. It can be seen in the work of Allport (1937), Buhler (1933) and Dollard (1935), and more recently in the work of Sarbin (1986), Bruner (1986), Mishler (1986), Polkinghorne (1988) and McAdams (1993). What these psychologists share is an interest in researching people's stories, in personal, rather than historical, truths (Hiles \& Cermak, 2008).

\section{The Voice of the Young Person}

If individual narratives are foregrounded and given authentic expression, then wider understanding of children who struggle can be developed

(Cefai \& Cooper, 2009, p. 32).

The importance of including the voice of the young person, if not their stories, in research is now relatively well established. Listening to young people may 'hold the key to our understanding of the problem and its resolution' (Davie, Upton \& Varma, 1996, p.7). Listening to the views of this particular group of children and young is particularly important if Cooper is right in his assertion that this group of young people are the 'least empowered and liked group of all' (Cooper, 2006, p.39). Furthermore, their views are likely to differ from the views of adults because of the disparity in accounts offered by teachers and those offered by the young people (Cefai \& Cooper, 2009). 
The paper adopts the position that we can learn from young people with SEBD and should seek to better understand their experiences without considering them 'impaired or invalid in some way' (Wise, 2000, p.144).

\section{Literature review}

The rest of the tapestry is not determined by what has been woven before. The weaver herself, blessed with knowledge and with freedom, can change - if not the material she must work with - the design of what comes next (Furman, 1998, p.22).

The negative risk factors associated with SEBD are well documented and include: learning difficulties, low educational attainment, school failure, lower life prospects and mental health difficulties later in life (Cefai \& Cooper, 2009). They suggest that young people with SEBD 'become victim to a system that labels them as failures, and does not provide the academic, social or emotional support that they need' (Cefai \& Cooper, 2009, p.48-49). More recently researchers have started to explore what helps young people with SEBD (Spiteri 2009, O'Riordan 2011). However, the vast majority of this research asks participants to look back at earlier school experiences. Shifting the focus from the past to the future can allow the young person to look at his identity through a different lens, no longer seeing himself as a victim of unfortunate circumstances' (Spiteri, 2009, p.245).

A systematic literature review was carried out in order to identify any research that had sought the views of young people with SEBD with regard to their future. The databases PsychINFO and PsychARTICLES were searched for peer-reviewed research that has been carried out with adolescents (13-17 years) over the last ten years. Only three research studies were found that focused on young people's views of their future and were relevant to the current research.

Solomon and Rogers (2001) encouraged young people to reflect back on their experience of mainstream school but also asked about their future plans for college and work. Whilst the future-focus formed a relatively small part of this research design, they found that the young people held unrealistic views of the future and appeared to lack agency and choice. 
Kloep, Hendry, Gardner and Seage (2010) explored the future selves of eleven 16-18 year olds from two deprived mining communities in south Wales. The researchers used the theoretical framework of 'Possible selves' (Markus \& Nurius, 1986) to explore these young people's view of themselves in the future. In particular, they sought to explore the potential risk and protective factors in the young people's stories. The findings indicated that although some of the young people felt their socio-economic environments constrained and limited their futures, others felt their circumstances presented future possibilities.

The psychological concept of possible selves was also used by Mainwaring and Hallam (2010), who sought to explore the hopes and aspirations of 41 young people in London. Comparisons were drawn between those attending a mainstream secondary school and others attending a Pupil Referral Unit (PRU). Students from the mainstream school were more likely to offer positive possible selves compared with those attending the PRU. Overall the PRU attendees were found to have fragile positive selves and to be more pessimistic about their future prospects.

\section{The value of Positive psychology}

Within positive psychology there is a significant body of literature evidencing the importance of focusing on the future. In particular, the importance of exploring how young people conceptualise the possibilities that lie ahead of them when they are still young.

A discourse of deficits provides continuing escalating difficulties, whereas a discourse of competence, strength and resilience promotes the amplification of those very qualities (Wagner \& Watkins, 2005, p.6).

The application of positive psychology to the area of young people with SEBD may at first appear unusual. Particularly given that positive psychology is usually concerned with normal and flourishing lives, and not those in need of help (Boniwell, 2008, p. 4). But with its focus on strengths, growth and potential, positive psychology is in direct 
opposition to a pre-occupation with risk and deficits and particularly relevant to future-oriented research. Cole and Knowles (2011) comment that the positive psychology approach, with its humanistic underpinnings, compliments much of what practitioners in educational settings are striving towards in their work with young people with SEBD. Of particular importance is the stance positive psychology takes towards negative experiences and the concept of post-traumatic growth; the potential earlier negative life experiences have to trigger an upward psychological spiral (Boniwell, 2008). Rather than ignoring the presence of negative experiences, positive psychology accepts that they are part of life and can actually build qualities.

\section{Methodology}

The aim of this research was to explore the stories that young people with SEBD tell about their future. It sought to identify the strengths and resources that have helped them build these stories.

A narrative methodology and life story approach was used to contextualise their stories and to explore the transactional nature of their experience over time.

The research was carried out in an outer London borough, with eight secondary-aged pupils in receipt of specialist provision, five of whom were female and three male. Not all of the young people had Statements of Special Educational Needs, but all were either at risk of exclusion or had already been excluded from their mainstream school. They were all deemed as having social, emotional or behavioural difficulties which was why they were not attending mainstream school.

The participants were informed that the research would go into the public domain and was therefore not confidential. However they were reassured that their stories would remain anonymous - and that any specific identification factors would be removed. For example, they were informed that the local authority in which the research was commissioned would not be named, because of the small data sample. Therefore details of the participants are limited to ensure their anonymity. As the young people were between 14 and 16 years of age informed written consent was obtained both from them and their parents, in line with the ethical guidelines laid down by the British Psychological Society's (BPS) Health and Care Professions Council (HCPC) and the 
University of East London. The young people were either interviewed at their education provision or at their home.

The research took a social-constructivist worldview. Lieblich, Tuval-Mashiach and Zibler (1998) propose that individuals know or discover themselves, as well as reveal themselves, in the stories that they tell. It was anticipated that each young person would construct their future selves differently, based on their own subjective experience. Unstructured, informant-style interviews, akin to those used by Powney \& Watts (1987), were drawn upon to maximise the potential for capturing individual meaning and variation across stories. It permitted the young people the freedom to tell their stories in their own way, facilitating the co-construction of deeper and richer data. A 'life path' (O'Riordan 2011) was also used in the interviews to provide the young people with a visual prompt. The life path helped them to structure their thinking during the interview, which was important given that many of them had difficult and/or chaotic stories to tell. It provided a shared focus and went some way in reducing the intensity of the interviews by removing the need for direct questioning thereby allowing participants to raise difficult issues in their own time (Wilson, Cunningham-Burley, Bancroft and Backett-Milburn and Masters 2007).

Each interview was divided into four phases.

Phase 1. Eliciting their narratives about the future - participants were encouraged to reflect on their future first, so that these narratives were elicited in their purest form, and the more sensitive stories of their past could be addressed later in the interview. Phase 2. Eliciting their narratives about the past - the life path was used to identify significant memories - beginning at the start of the life path labelled '0-5' years of life . Phase 3. Identifying the strengths \& resources in their lives - participants identified protective factors that had helped them get through the life events they had described in the second phase of the interview.

Phase 4. Exploring how these strengths and resources could help them in the future the young people reflected on how the strengths and resources drawn on in the past could help them in the future.

Narrative analysis 
The current research drew on Hiles and Cermak's (2008) model of 'Narrative Oriented Inquiry' (NOI) which is rooted in the principles of narrative psychology. This involved breaking the text down, before adopting a number of interpretive perspectives and applying these to the text, working through the narrative repeatedly asking different questions of it each time (Langdridge, 2007). Figure 1 illustrates the steps taken to reconstruct past and future narratives.

\section{Figure 1. The six steps taken to re-construct past and future narratives}

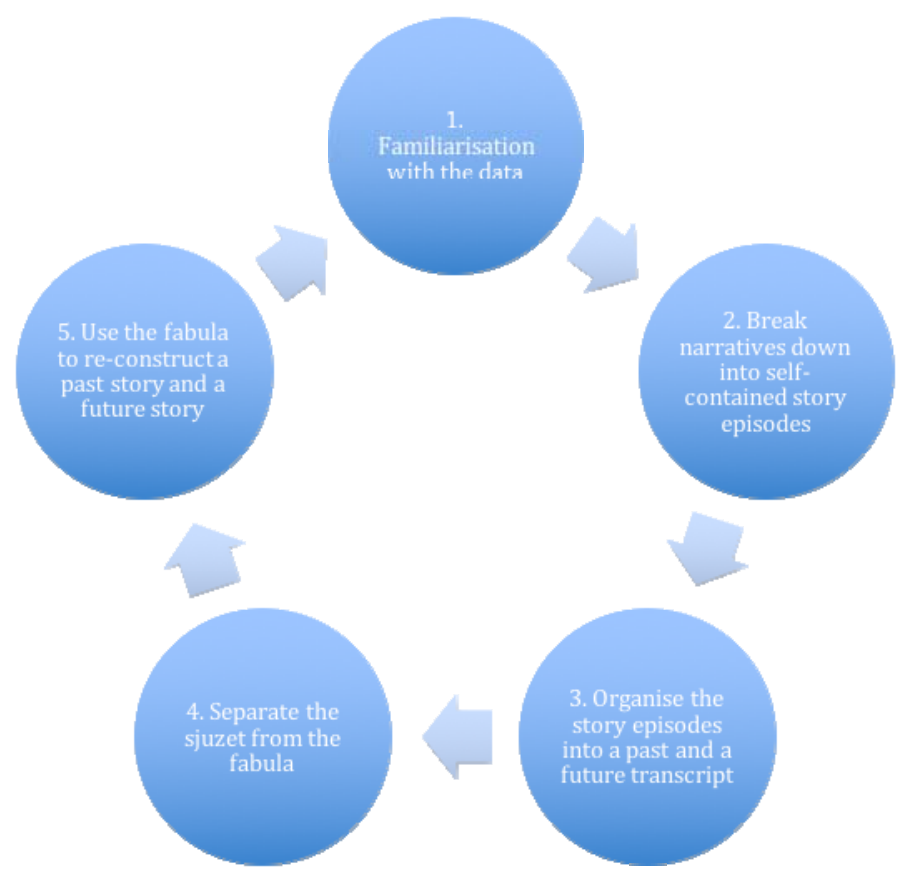

1. Familiarisation with the data: The transcribed interviews were read and re-read building a picture of the stories as a whole in order to gain a sense of the young people's experiences and the meaning they attached to these.

2. Breaking the narratives down into self-contained story episodes: These initial readings facilitated identifying moves in the telling of the story, in order to break the whole narratives down into separate smaller self-contained story episodes.

3. Organising the story episodes into a past and future transcript: Each self-contained story episodes was then divided into past and future stories.

4. Separating the sjuzet from the fabula: The bounded aspects of the stories - what was being told (the fabula) - were separated from the unbounded - the way in 
which it was told (the sjuzet). The sjuzet included words, phrases or sentences that reflect emphasis. Reflection or asides, which are not essential to the story but influence how it is re-told.

5. Using the fabula to re-construct past and future stories: The fabula was then read as a simple story, beginning with the past and ending with the future.

6. Adding necessary sjuzet to the re-constructed stories for authenticity: Sjuzet was then added in, to reflect the young people's expression, particularly those remarks that conveyed significance and added authenticity to the way in which they had told their stories.

Next the central interpretative analysis - a categorical-content analysis - was carried out on each young person's future story. Figure 2 depicts the steps taken, which involved identifying principle sentences and exploration of positive themes within the story. Themes of potential, growth and any other factors that the young people deemed to have helped them were included.

Figure 2. The four stages of the categorical-content analysis

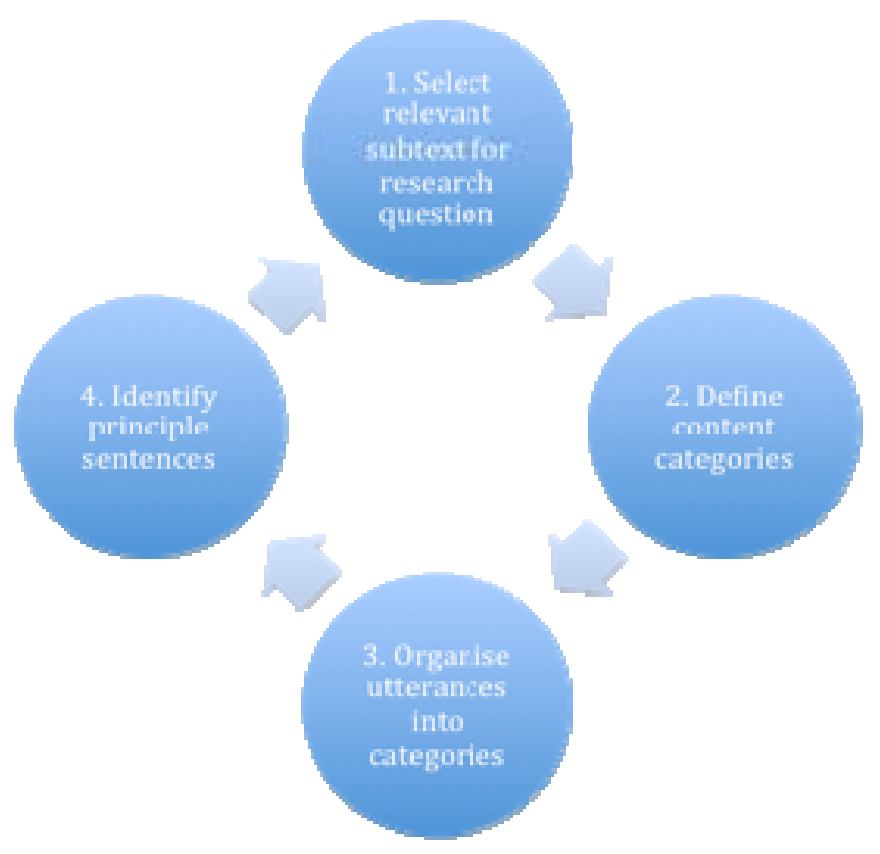


1. Selecting the relevant subtext for research question: This requirement was fulfilled through the choice of research question, which identified the future story as the primary subtext on which the analysis would focus. Though it was accepted that earlier readings of the past story would have informed this analysis.

2. Defining the content categories: The theoretical orientation of positive psychology informed the reading of the future stories, rather than allowing themes to emerge from the text in a grounded theory manner. Themes that pertained to the potential for growth, strengths and resources were sought across the young people's stories. The young people's own words were used as category descriptors.

3. Organising the utterances into categories: The stories were re-read several times to identify clusters of meaning.

4. Identifying the principle sentences: Principles sentences were chosen to represent each category.

\section{Findings}

The findings presented in this paper focus on the way the young people drew on the resources and strengths from their past when constructing a story about their future, and so future stories can only be understood within the context of the past. Only two of the eight stories are presented here as exemplars. They were chosen to illustrate the breadth of experiences, strengths and qualities identified, with the first told from a male perspective and the second from a female. The two stories that follow, first Tommy's and then Paige's, depict a rich and differential picture of the future envisaged by two young people with SEBD who were not attending mainstream school.

\section{Tommy's past}

'...I'm Fourteen...I've travelled my whole life...my family come from gypsy families......... hate school but I've gotta put my head down cause last year I was, like, on the verge of getting expelled...I've been brought up around older people.......people told me if it weren't for my mum I would have been in prison by now...I was putting her through hell, not just in school but out of school as well, getting arrested and stuff...it's just respect innit, respect for my mum...' 


\subsubsection{Tommy's future}

'...l'd like to coach or something teaching football, like go round different schools and that...whenever I got to do my work experience...that's when I am gonna try and start it...that's something which school's helped with, like encouraged me with even more....I do football outside of school as well....nearly semiprofessional...or construction...it's just another thing I enjoy doing with my hands instead of sitting down writing...I do a bit of work with my cousin and my uncle...my cousin does electricity, he's got his own electricity company....my other brother is a designer like decorator and my dad just does stuff...anything with construction...probably own my own construction company or something... I've always wanted to do something like that...

...or it could turn out to be coaching...it could turn out to be either... study it at college, that's all I can do, get better at it...I just want to go straight to college...get working quick time...I wanna get out like, I dunno, the way I've grown up a bit quicker for my age, so I just wanna get on with it...I hate school but I know I've got to get through school so I can get money and get a job and that...my mum's always getting me on track...my brother's grown up a bit now, like from what he used to be....I'm not too sure what I'm going to be like...

...I want to go to America when I'm older...get away from everything...it depends. I might not, it just depends on what I'm doing here and how I'm getting on...I'm going into a hostel when I'm sixteen...I just want to get out, just want to start earning my own money...that and other stuff as well...after a year in a hostel you get a flat anyway don't you...the council gets you a flat...maybe saving my money and getting a house...If I put my mind to something I will do it...depends what I put my mind for...even if I hate school but I know I've got to get through...just want to move to a better place you know...it's like perfect innit really, it's just money, everything, big house....better than here, it's all just...'

Examples of Principal Sentences and Their Categorisation: Tommy

\begin{tabular}{lll}
\hline \multicolumn{1}{c}{ Principle sentence } & \multicolumn{1}{c}{ Category } & \multicolumn{1}{c}{ Comments } \\
\hline $\begin{array}{ll}\text { 'I do a bit of work with } \\
\text { my cousin and my uncle' }\end{array}$ & $\begin{array}{l}\text { Positive learning } \\
\text { opportunities }\end{array}$ & $\begin{array}{l}\text { His aspirations stem from } \\
\text { positive opportunities i.e. } \\
\text { working with his family } \\
\text { and football, which have } \\
\text { left him feeling proud and } \\
\text { like he has experience on } \\
\text { which to build. }\end{array}$
\end{tabular}




\section{bit now'}

'My mum's always getting me on track' and negative role models in his story. Importantly he aligns himself with positive role models.

Family support

His mum has kept him at school and out of prison. She has earned his respect and he wants to make her happy. She has contributed to his motivation for a better life in the future.

\subsubsection{Analysis of Tommy's story}

\section{Strengths and resources}

Tommy has been able to capitalise on practical opportunities to explore potential careers for the future. He has had opportunities to develop his football skills in and out of school, something he is proud of and something that school has helped him with (lines 5-6). He has also had the chance to learn about the construction trade by working with his cousin and uncle (lines 7-8). These opportunities have left him feeling that he has options (line 6) and enabled him to identify work that he might be suited to (lines 6-7). They have also given him the confidence to pursue these careers. He views his forthcoming work experience as an opportunity to build on these experiences (lines 2-3), and even talks of owning his own construction company one day (lines 11-12).

Tommy refers to a number of role models in his narrative (lines $8-11$ ). He tends to position himself alongside positive role models, such as his uncle and his cousin (line 11-12), as apposed to other less positive role models (lines 21-22). Family support is a theme across his past and future stories, with his mum central to his narrative. In his past story, Tommy explains that he is close to his mum, describing the ways in which she keeps him on the right track and out of trouble. He explains that he is sticking it out at school because he respects her and wants to make her happy. Overall, he positions her as someone who has done her best to give him a better chance in life and has inspired him to work hard to achieve this in his future. 


\section{Paige's past}

'...It's a three bedroom house... ... there's fifteen of us all together...My mum passed away...I was 18 months...then one day, my dad, he just needed a break for a couple of years...just had a nervous breakdown...a stroke and everything...my dad passed away...There are some dodgy people that turn up round the area...the safer neighbours team just don't do anything... I got chased down the road, they just drove straight past ...I got kicked out of [name of previous school]...I had tuition for six or seven months and then they found me a place here...coming here [helped]...they teach about, you learn...all these lot here

\section{Paige's future}

1 '...College...childcare or hair and beauty...I really love kids... 2 ...probably go to university or something...my sister...she got all 3 As in her GCSEs in year 11 and I thought 'Wow' like, considering 4 you didn't go to school for two years...[or] buy my own 5 salon....my mate, she's eighteen now and she's just opened up 6 her own salon and she's made so much rich....making a life of 7 business....she's got money coming in left, right and 8 centre....works everyday...money innit...

10 ...Social Services...when you hit eighteen, for the first two 11 years...they will pay your rent and all your bills...those two years 12 will be covered...if my nan was still alive I would be living with my 13 nan...if she did pass away I would probably have her house and 14 still live in the same area...we want our kids to be brought up in 15 the area that we've been brought up in...my nan and granddad 16 have lived there all their life, and my mum lived there until she 17 passed away and my dad lived there until he passed away...so, 18 basically the whole family has just been brought up...if you move 19 somewhere else you're not really going to know anyone there, 20 whereas round there you're going to know everyone...some of 21 the little kids round there they're like, can sometimes be a little 22 bit funny but i'll teach my kids the right way...the one thing I 23 don't want...my cousin, he's had two kids...and they split up...he 24 had to sign this contract, saying I will see the kids twenty-four 25 hours after...

...well when you're a grown up, you look back and you think, 'Oh I really regret doing that, I really wanna go back and do it again'...everytime I walk past my primary school...I always wanna go back and do it again...run round with your friends......you just miss the screaming of the kids and the bell goes off. Or when you're in assembly...every Friday we used to sing hymns and I always miss doing that...me and my mate...we're always thinking back on the songs. And we always used to sit there in our own little world just singing them...it's different now...in secondary they're so much stricter...'Just knuckle down and get on with it'... 
$38 \quad . . . I^{\prime} m$ getting $\mathrm{my}$ first qualification in year 9...Functional Skills

39 level $1 . .$. [if I didn't]...I wouldn't get no GCSE's, wouldn't get no

40 qualifications, wouldn't get a job...l thought of my education,

41 that's what I've really got to think about...forgetting about all the

42 childish stuff I used to do. Getting on with my life...' 


\section{Examples of Principal Sentences and Their Categorisation: Paige}

\begin{tabular}{l} 
Principle sentence \\
\hline \\
'My mate, she's eighteen
\end{tabular}

'If you move somewhere else you're not really going to know anyone there whereas round there you're going to know everyone'

'I'm getting my first qualification in year 9'
Belonging

Her family home and the area that she has been brought up in are extremely significant to her. She knows she will always have a place in her nan's home. Everyone knows her in the area and in provision $\mathrm{A}$.

Positive learning opportunities
Achieving her first qualification has given her a sense of pride and motivated her to focus on her education and future. She has been able to learn at provision $A$.

\subsubsection{Analysis of Paige's story}

\section{Strengths and resources}

Paige hopes to go to college and has been inspired by her sister who, despite ill health, managed to get the grades needed for college (lines 2-4). She has also been impressed by the amount of money her friend is making (lines 5-8) and acknowledges how hard she works (lines 8). Paige's nan is a significant role model who features across her past and future stories. This is exemplified in her past story, when she explains that her nan is helping her neighbours to learn English, as well as other instances in Paige's narrative where she discusses the impact less positive role models have had on her. Importantly Paige identifies how she would like to do things differently (line 22-25). 
Many of the role models that Paige refers to are family members. The significance of family and a sense of belonging is a re-occurring theme across her past and future stories. The local community and family home are important to her (lines 13-20) and have left her and her sister committed to raising their own families in the same area. The family home serves as a reminder of those she has lost as well as those that she still has, and Paige knows that she will continue to have a place there for as long as she needs it (lines 12-14). This sense of belonging extends to her experience at provision $A$. In her past story she explains that she has known some of her peers her whole life, and describes the ways in which they look out for her. She also views Provision A as a positive experience because she has been able to learn there. In her future story Paige spoke with pride about securing her first qualification in year 9 (lines 38 ). This appears to have motivated her to work towards getting her GCSEs and a job in the future (lines 39-40).

\section{Discussion}

We can't change history - events in the past that have actually happened...yet we can - to a surprisingly high degree - influence the way we perceive past events and what they mean to us. The past...[is] a story that's alive and changing as it's being retold, given new emphases, meanings, explanations and consequences (Furman 1998, p. 114).

The earlier literature paints a rather bleak picture of the circumstances that these young people grow up in and suggests they lack the resources to cope. The findings of the current research directly challenge this view and demonstrate that, when asked the right questions, young people with SEBD identify a range of strengths and resources in themselves, their schools, their family and their community. Whilst there are some similarities across the young people's stories, overall each young person presented a unique combination of strengths and resources reflecting the individual nature of their experiences. Though only two stories are illustrated here, all eight were drawn upon in order to inform the Discussion section. McAdams (1985) suggests that the stories we tell ourselves 'bring together diverse elements into an integrated whole, organising the multiple and conflicting aspects of our lives' (p.198-99). This research demonstrated that young people with SEBD discuss a unique combination of strengths 
and resources in their stories and professionals need to explore how the different levels of their system interact to produce multiple strengths and resources.

\section{Resources in the school and broader learning environment}

\section{Positive relationships with staff and peers}

In the current research the young people identified a wealth of resources associated with the alternative provisions they were placed in. They described the positive relationships they had built with staff and acknowledged getting the support that they needed, both academically and emotionally. Some of the young people alluded to feelings of belongingness associated with the alternative provisions, exemplified by Paige who explains that she has known many of the other young people in the provision for her whole life.

\section{Feelings of agency in relation to their learning}

Spiteri (2009) also found that attending an alternative provision instilled a sense of responsibility in his participants. The current research supports these findings, with many of the young people describing their attendance at the alternative provisions as a turning point in their lives. Many also described experiencing a renewed sense of agency in relation to their ability to learn. Spiteri (2009) concludes that an alternative provision provided his participants with 'access to discourses that enabled them to interpret the world differently'.

\section{Learning opportunities of relevance to the future}

The young people identified practical learning opportunities and described the direct relevance these had to their futures; Tommy describes the ways in which he plans to capitalise on such opportunities in the future. Paige was proud that she had been able to secure her first qualification in Year 9, which left her motivated towards securing more in the future. Ultimately, within these alternative contexts, the young people were able to access positive learning experiences. These experiences enable them to recognise that they have skills and options available to them. They experienced being good at something - sometimes for the first time - and identified work that they might be suited to in the future. Importantly, these positive learning experiences extended across the home and school contexts. 


\section{Resources in the family and broader social context}

In her research with young people with SEBD, Wise (2000) identified the following risk factors associated with the family and broader social experiences: loss of parents through family breakdown or death, violence in the home, inappropriate role models, caring for a parent, being in care, poverty, class, self-image and cultural expectations associated with being part of an unacceptable cultural group. Many of these factors feature in the stories told by the young people in the current research. However it is significant that many also identified the following resource in their families and broader social contexts:

\section{Positive role models}

Positive role models were a common theme across the young people's narratives. Tommy chose to align himself with his uncle and cousin, rather than other, less positive role models in his life. Similarly, Paige chose to align herself with her sister, someone she looked up to.

\section{Family support}

Family support was of great significance in many of the young people's stories. Tommy's mum was central to his narrative. She kept him on the right track, wanted to give him the best chance in life and her happiness was, ultimately, what motivated him to stay in school. Paige expressed a desire to live close to her family when she is older and it seems her family, home and community contributed to her feelings of belongingness in the absence of her parents.

\section{Strengths in the self}

Wise (2000) found that young people with SEBD often report feeling different, in particular not being able to learn and blaming themselves for their difficulties. The current research supports these findings and the young people described feeling different in their mainstream schools. However many of those in the current research also acknowledged a number of strengths within themselves including: pride, desire to make a nice life for oneself, self-belief and self-determination. 


\section{Future Selves}

These young people's ability to attribute positive meaning to exceedingly challenging circumstances is a credit to them. What they have learnt from their experiences is significant, not only in the way they view their past in the present, but in relation to their future selves. Self-determination, self-belief, optimism and positivity are all qualities that will help them in the future. These findings support the earlier findings of Kloep, Hendry, Gardner and Seage (2010) who found that young people from deprived backgrounds are able to look beyond their difficult circumstances, to acknowledge the possibilities such circumstances present for the future. The findings also directly challenge suggestions that SEBD develops in children and young people who lack resilience, the ability to bounce back from adversity (Cole \& Knowles, 2011). Each of these young people can be considered to have faced adversity, bounced back and developed qualities as a result of their earlier negative experiences.

Six of the eight young people demonstrated qualities they had built up as a result of earlier negative experiences, these include:

○ Determination to secure a better life for oneself in the future, as a result of growing up with little money

- Self-determination in the face of adversity, as result of an unexpected pregnancy

- An optimist and positive outlook, as a result of earlier negative school experiences

- Determination to work hard, as a result of being at risk of permanent exclusion

- Adopting a more empowering discourse in relation to one's ability, as a result of earlier negative school experiences pertaining to undiagnosed dyslexia

A strong sense of self-belief, as a result of having a great deal of 
responsibility as a child

These young people identified a number of strengths and resources that held strong significance for them in their past, present and future lives. Fundamentally, they demonstrated that young people with SEBD do have, and are able to identify, strengths and resources in their lives. As Boyden and DeBerry (2004) write, there is a need for a more rounded approach in research in order to provide a holistic view of children and young people in relation to stressful circumstances. This research has demonstrated the potential contribution a strength-based approach can make to our understanding of young people with SEBD.

It demonstrates that positive psychology, which aims to discover and promote the factors that allow individuals and communities to thrive, is a useful theoretical orientation on which to draw, in order to develop new understandings of young people with SEBD. Of particular use, is the focus positive psychology places on the potential for growth in the future. A strength-base and future-focus may be a more effective way of addressing the issue of SEBD, and has the potential to ensure that the voices of some of the most vulnerable students are heard and impact upon policy and development of appropriate provision and resources.

\section{Limitations}

The real-world nature of this research meant that a number of ethical and pragmatic challenges were confronted, with implications for both the current and future research. Firstly, permission was required from multiple gatekeepers, with access to some dependent upon access to others. Secondly, considerable thought had to be given to the subtleties and pressures surrounding 'informed' consent. It took time to build trust and to work towards address power imbalances and involved gradual entry into the field, by spending time getting to know the young people 'on their turf' first. Further issues were confronted when it came to carrying out the interviews; managing differences in interviewing across home and provision contexts, balancing the need to establish rigour whilst ensuring wellbeing, and managing the reality of multiple interruptions are just a few examples. There was also the issue of identifying an 
appropriate model of narrative analysis with, as Howitt (2010) writes, models 'harder to come by' and theory 'more difficult to clarify' in narrative research. Despite these limitations, this research offers an insight into the individual meaning these young people can make when asked to describe their lives.

\section{Implications: For practice}

\section{Using a Narrative approach to gain a rich picture}

The current research has demonstrated that, by adopting a narrative approach and imposing less structure on the young people's accounts, rich information can be gained. Narrative as a method of interviewing proved to be very successful in facilitating the young people to talk about their lives. Within a short space of time they revealed rich, detailed and personal information about themselves. Furthermore many narrative researchers suggest that a primary way that people make sense of their experiences is by telling their 'story'.

Although 'story' as a research tool is a relatively new concept in the social sciences, historically it has been an accepted way of relaying knowledge (Bell, 1999). The 'thick description' that it produces has the potential to be exceedingly powerful. Robson (2011) acknowledges the way in which this type of research can resonate with readers' informal understandings, allowing them to see parallels between the participant's lives and the situations in which they themselves work (Robson, 2011, p.73-74). 'Story' as an approach also has the ability to allow readers who do not share an understanding of the subject to relate to the research.

\section{Implications for Educational Psychologists}

Within this research there are a number of implications for EPs working within Children's Services, given their particular position in supporting stakeholders to construct meaning and promoting understanding that change is possible. Examples include using the approaches outlined here to: help build positive relationships between young people and members of staff, ensure young people receive the most appropriate provision to meet their needs and to focus support on building a sense of growth and potential. EPS are also very well placed to carry out more in-depth work with children and young people, in order to help them to facilitate a sense of 
coherence over their lives and embrace more empowering narratives.

\section{Using the life path to facilitate a sense of coherence}

From a constructivist perspective, it is accepted that the meanings made by adults may differ significantly to those of young people. Therefore in order to understand the meaning a young person attributes to their experience, we need to ask them about it. The success of the tool used in the current research - the life path - could be replicated with other young people with SEBD with implications for EPs working to elicit young people's views. This is particularly important in light of the new SEN code of practice (2014), which places great emphasis on children and young people's voices and there are, for example, implications for applying the life path tool and narrative approaches in our contributions to Education, Health and Care Plans (EHCP). Hiles and Cermak (2008) highlight that when using narrative approaches to explore the meaning an individual gives to their life, the narrative resources of the individual are key, and not the interpretive skills of the listener. By using the life path tool with young people with SEBD professionals can facilitate their narrative resources.

At the most basic level, using the life path approach with young people with SEBD will facilitate their thinking, allow them to feel listened to and validate their experiences. But the approach may also go some way in supporting young people to attach meaning to their experiences, to gain insights into their feelings/behaviour and to develop a sense of coherence over their lives. This is particularly important for young people with SEBD, given that narrative can provide 'scattered and often confusing experiences with a sense of coherence by arranging episodes of our lives into stories (McAdams, 1985, ibid. 11).

\section{Using the life path to embrace more empowering narratives}

The life path can also be used in a more therapeutic way. Within narrative psychology, it is accepted that the way in which people 'story' and 're-story' their experiences constructs their own identity (White \& Epson, 1989, p.13). Hoffman (1990) suggests that problems are the stories people tell themselves in the absence of alternative and more empowering stories. If we accept that we are the assembled stories that we tell about ourselves, then it is possible that we have the power to 'tell more empowering 
stories' (Hiles \& Cermak, 2008, p. 149). It is through this process of 're-telling', that we are able to inhabit and live out new alternative stories (Freedman \& Combs, 1996).

Professionals in the LA can encourage young people with SEBD to use the life path to identify strengths and resources in their lives. This may go some way in preventing feelings of helplessness, may encourage them to embrace more empowering and positive narratives and help them to take a more optimistic view of what they can achieve in the future. By engaging in this process, practitioners will shift their focus from the problem to the solution, which has the potential to make young people feel as though they are more than their problem.

\section{The end product: A collaborative narrative}

Ultimately, it is our retelling of these young people's stories that is the story told here. Emphasis is placed on the uniqueness of the individual stories, acknowledging their pasts, future aspirations and most importantly of all, their potential for growth. The young people's views have been combined with our own to form a collaborative narrative (Clandinin \& Connelly, 2000) and to produce multiple meanings, which we believe have been 'transforming' for us and the reader (Etherington, 2009). We hope that this research offers an alternative and more empowering narrative of young people with SEBD, and will go some way in altering the way in which these young people are perceived in the future.

\section{References}

Allport, G. W. (1937). Personality: A Psychological Interpretation. New York: Holt, Rinehart and Winston.

Bell, J. (1999). Doing Your Research Project: A Guide for First-Time Researchers in Education and Social Science ( $3^{\text {rd }}$ ed.). Buckingham: Open University Press.

Boniwell, I. (2008). Positive Psychology in a nutshell ( $2^{\text {nd }}$ ed.). London: Personal WellBeing Centre.

Boyden, J. \& de Berry, J. (2004). Children and Youth on the Front Line: Ethnography, Armed Conflict and Displacement. Oxford: Berghahn Books.

Bruner, J. (1986). Actual Minds, Possible Worlds. Cambridge, MA: Harvard University Press. 
Buhler, C. (1933). The Human Course of Life as a Psychological Problem. Leipzig: Hirzel.

Cefai, C. \& Cooper, C. (2009). Promoting Emotional Education: Engaging Children and Young People with Social, Emotional and Behavioural Difficulties. London Philadelphia: Jessica Kingsley Publishers.

Cole, T \& Knowles, B. (2011). How to Help Children and Young People With Complex Behavioural Difficulties: A Guide for Practitioners Working in Educational Settings. London Philadelphia: Jessica Kingsley Publishers.

Cooper, P. (2006). 'John's story: Episode 1 - Understanding SEBD from the inside: The importance of listening to young people'. In M. Hunter-Carsch, Y. Tiknaz, P. Cooper, and R. Sage (Eds.), The Handbook of Social, Emotional and Behavioural Difficulties. London: Continuum International Publishing Group.

Davie, R., Upton, G., \& Varma, V. (1996). The Voice of the child: A Handbook for Professionals. Oxon: Routledge.

Dollard, J. (1935). Criteria for the Life History. New Haven CT: Yale University Press.

Freedman, J. \& Combes, G. (1996). Narrative therapy: The social construction of preferred realities. New York: Norton.

Furman, B. (1998). It's never too late to have a happy childhood: from adversity to resilience. London: $\mathrm{BT}$ Press.

Hiles, D., \& Cermak, I. (2008). Narrative psychology. In C. Willig \& W. Stainton-Rogers (Eds.), The SAGE Handbook of Qualitative Research in Psychology. (pp. 147-164). London: Sage.

Howitt, D. (2010). Introduction to Qualitative Methods in Psychology. Essex: Pearson Education Limited.

Hoffman, M.L. (1990). Empathy and justice motivation. Motivation and Emotion, 4, 151-172.

Kloep, M., Hendry, L. B., Gardner, C., \& Seage, C. H. (2010). Young People's Views of Their Present and Future Selves in Two Deprived Communities. Journal of Community \& Applied Social Psychology, 20, 513-524.

Langdridge, D. (2007). Phenomenological Psychology: Theory, Research and Method. Essex: Person Education Limited. 
Lieblich, A., Tuval-Mashiach, R. \& Zibler, T. (1998). Narrative Research: Reading, Analysis and Interpretation. London: Sage Publications.

Mainwaring, D. \& Hallam, S. (2010). 'Possible selves' of young people in a mainstream secondary school and a pupil referral unit: A comparison. Emotional and Behavioural Difficulties, 15 (2), 153-169.

Markus, H., \& Nurius, P. (1986). Possible selves. American Psychologist, 41 (9), 954-69.

McAdams, D.P. (1985). Power, intimacy, and the life story. New York: Guildford.

Mishler, E. G. (1986). Research Interviewing: Context and Narrative. Cambridge, MA: Harvard University Press.

Mishler, E. G. (1986). The analysis of interview-narratives. In T. R. Sarbin (Ed.), Narrative Psychology: The Storied Nature of Human Conduct. New York: Praeger.

Murray, M. (2008). Narrative Psychology. In J.A. Smith (Ed.), Qualitative Psychology: A practical guide to research methods ( $2^{\text {nd }}$ ed.). (pp. 111-132). London: Sage.

O'Riordan, Z. (2011). Living in the 'real world': the experiences and support of schoolleavers with social, emotional and behavioural difficulties. Emotional and Behavioural Difficulties, 16 (3), 303-316.

Polkinghorne, D. E. (1988). Narrative Knowing and the Human Sciences. New York: State University of New York Press.

Powney, J. \& Watts, M. (1987). Intervening in Educational Research, London: Routledge and Kegan Paul.

Robson, C. (2011). Real world research: A resource for social-scientists and practitionerresearchers. Oxford: Blackwell Publishing.

Sarbin, R., T. (1986). Narrative Psychology: The Storied Nature of Human Conduct. New York: Praeger.

Spiteri, D (2009). Forging an identity over the life-course. Emotional and Behavioural Difficulties, 14 (3), 239-249.

Wagner, P \& Watkins, C. (2005). Narrative work in schools. In A. Vetere \& E. Dowling. (Eds.). Narrative Therapies with children and families: a practitioners' guide to concepts and approaches. London: Routledge.

White, M., \& Epson, D. (1989). Literate means to therapeutic ends. Adelaide, South Australia: Dulwich Centre Publications.

Wilson, S., S. Cunningham-Burley, A. Bancroft, K. Backett-Milburn, and H. Masters. (2007). Young people, biographical narratives and the life grid: Young people's accounts of parental substance use. Qualitative Research $7(1), 135-31$. 
Wise, S. (2000). Listen to Me: The Voices of Pupils with Emotional and Behavioural Difficulites. Bristol: Lucky Duck Publishing Itd. 